\title{
Vine spacing on cv. Tempranillo in the Appellation of Origin Cigales (Spain): Agronomy and quality effects
}

\author{
Jesús Yuste ${ }^{1}$ and María Alburquerque ${ }^{2}$ \\ ${ }^{1}$ Instituto Tecnológico Agrario de Castilla y León, 47071 Valladolid, Spain \\ 2 At present: viticulture advisor, Valladolid, Spain
}

\begin{abstract}
This paper studies the vegetative, productive and qualitative behavior of the Tempranillo variety, vertically trellised trained, according to a placement of vines with three different distances $(1.04,1.40$ and 1.80 meters) in the row and a common distance between rows ( 2.40 meters), in order to determine the most suitable vine distance for the growing conditions. The experimental test has been developed for the period 2007-2011 in the Appellation of Origin Cigales, in Valladolid (Spain). The reduction of vine distance has favored the vegetative growth, through the shoot weight, while the grape yield has been slightly higher in the intermediate vine distance, $1.40 \mathrm{~m}$, through the cluster weight. Ravaz index showed some increase with the increasing of vine distance, derived from the decrease of pruning wood. In qualitative terms, the variation of the vine distance did not significantly modify the basic composition of the grape. Therefore, the choice of the vine distance involves the convenience to assess both potential effects in terms of production and economic objectives of the new plantations, in accordance with the characteristics of each growing situation.
\end{abstract}

\section{Introduction}

The definition of planting density should always be included among the fundamental aspects in planning a vineyard plantation due to the impact that vine density carries out for vineyard profitability all throughout the entire life of the crop. It should be kept in mind that the producer tries to design the planting of vineyards, including the choice of vine density, in order to maximize his profitability. Thus, the goal of the operation is often trying to combine a satisfactory amount of crop with a considerable quality of grapes. Therefore it is convenient to assess how planting density may be the most appropriate to maximize grape quality and optimize the performance of the vineyard depending on soil and climatic growing conditions [1], as this choice can be decisive for the chances of success for future vineyard since it is going to condition many technical aspects in the vineyard management.

The planting density is a function of two parameters: the spacing between rows (street width) and the distance between vines within the row [2]. In choosing the distance between rows mainly influence the possibilities of mechanization [3], while in the choice of vine spacing influence more aspects related to the type of pruning [4], the permanent structure of the plant [5], the production level and the dynamics of maturation [6], etc. In any case, the choice of vine density should consider its two components, the distance between rows and the distance between vines in the row [7].

Some studies have shown that planting density directly affects the yield and quality of grape $[8,9]$. In this sense,
Planas [10] observed in high planting densities, in the French region of Audois, that the grape yield per hectare was higher and the grape yield per plant was lower than those of low planting densities. This increase in grape production per hectare in a high density vineyard was accompanied, in general, by a more complete, earlier maturity and a better quality of wines (red wines with more color, more concentrated), which was explained by an improved root colonization of soil, an effective capturing of light energy and a competition between individual vines that limit the individual vigor. However, other authors have found variable effects of vine density, which were dependent on the crop situations [11-15].

The purpose of this work is to study the possible effects of varying the distance between vines, maintaining a common distance between rows, in the vegetative and productive development, as well as in the quality of the grape, of the red variety Tempranillo, vertically trellis trained. The study has been developed over a five years period, in an experimental vineyard located in the Appellation of Origin Cigales, in Valladolid, therefore, in a situation of crop growing and typical semi-arid climatic conditions of the center of the Duero River valley.

\section{Material and methods}

The trial was carried out over the period 2007-2011 in the municipality of Cigales (Valladolid), belonging to the D.O. Cigales, in the Duero River valley. The geographical coordinates of the trial are $41^{\circ} 47^{\prime} \mathrm{N}$ and $4^{\circ} 41^{\prime} \mathrm{W}$, with an altitude of $780 \mathrm{~m}$ a.s.l. The vines of the experimental 
Table 1. General physical-chemical characteristics of horizons $(\mathrm{cm})$ of soil profile in the experimental vineyard. Values of Coarse Eements (C.E.), Sand, Silt, Clay in \%, and Texture and $\mathrm{pH}$.

\begin{tabular}{|lcccccc|}
\hline Depth & C.E. & Sand & Silt & Clay & Texture & pH \\
\hline $\mathbf{0 - 2 5}$ & 8.3 & 46.6 & 30.5 & 22.8 & Loam & 8.5 \\
\hline $\mathbf{2 5}-\mathbf{4 0}$ & 13.0 & 48.2 & 27.3 & 24.4 & Loam & 8.5 \\
\hline $\mathbf{4 0 - 6 5}$ & 9.6 & 45.0 & 28.9 & 26.0 & Loam & 8.6 \\
\hline $\mathbf{6 5 - 9 0}$ & 36.2 & 46.7 & 25.7 & 27.6 & LoClaSa & 8.7 \\
\hline$>90$ & gravel & & & & & \\
\hline
\end{tabular}

vineyard, planted in 2002, are of cv. Tempranillo, grafted onto the rootstock $110 \mathrm{R}$.

The vines have been vertically trellis trained with bilateral Royat cordon and vertical shoot positioning $(V S P)$, whose row orientation is North-South. The pruning load has been 10 buds per linear meter of trellis, distributed in 2 buds spurs. A green pruning operation was applied each year, after the period of risk of spring frost, for the adjustment of shoot load per linear meter of row.

The experimental treatments are based on the modification of planting density by varying the distance between vines in the row. Thus, maintaining a common row distance of $2.40 \mathrm{~m}$, the following distances between vines were applied: $1.04,1.40$ and $1.80 \mathrm{~m}$. These distances correspond to the following area of soil per vine: $2.50,3.36$ and $4.32 \mathrm{~m}^{2}$, that is, the vine density is 4,000, 2,976 and 2,315 vines per ha respectively. The experimental design is a randomized block with 4 replicates of 30 vines and elemental plot of 10 vines of control.

The soil of the vineyard, slightly stony on surface ( $10 \%$ small gravels), is developed on Miocene sandstones, in a site with soft slope in general, less than $3 \%$, and has good ground drainage. The general characteristics of the soil profile of the trial are shown in Table 1. This would be a soil classified as Haploxeralf calcic. The apparent density of the soil profile (in the first meter of depth) ranges from 1.66 to $1.83 \mathrm{~g} / \mathrm{cm}^{3}$ (decreasing in depth). The content of calcium carbonate $\left(\mathrm{CaCO}_{3}\right)$ varies between 6.5 and $41.2 \%$ (increasing in depth), while the active lime content varies between 3.6 and $13.2 \%$ (increasing in depth). The phosphorus content is very low (less than $3.02 \mathrm{mg} / \mathrm{kg}$, decreasing in depth) and potassium content is mediumhigh (between 44.4 and $273.0 \mathrm{mg} / \mathrm{kg}$, decreasing in depth).

The water regime of the vineyard has basically been rainfed, but with application of deficit irrigation support some years. Thus, in 2007 and 2008 vines were not irrigated. In 2009 an irrigation of $10 \mathrm{~L} / \mathrm{m}^{2}$ was applied (August $11^{\text {th }}$ ). In $2010,20 \mathrm{~L} / \mathrm{m}^{2}$ of water were applied in two irrigations (July $23^{r d}$, August $3^{r d}$ ), $10 \mathrm{~L} / \mathrm{m}^{2}$ each. In $2011,43 \mathrm{~L} / \mathrm{m}^{2}$ were applied in five irrigations of $8.5 \mathrm{~L} / \mathrm{m}^{2}$ (June $1^{\text {st }}$, July $16^{\text {th }}$, July $28^{\text {th }}$, August $1^{\text {st }}$, August $\left.30^{\text {th }}\right)$. Irrigation was applied through pressure compensating emitters of $2 \mathrm{~L} / \mathrm{h}$, which were separated by $0.75 \mathrm{~m}$ along the pipe. Average monthly rainfall and temperature data, for the period 2007-2011, are detailed in Table 2.

The statistical analysis of results has been done through variance analysis (ANOVA), by means of the STATISTICA program.
Table 2. Temperature and rainfall values as average of the period 2007-2011, registered at the weather station next to the experimental vineyard in Cigales (Valladolid, Spain). Tm: average temperature $\left({ }^{\circ} \mathrm{C}\right)$, Tmax: average maximum temperature $\left({ }^{\circ} \mathrm{C}\right)$, Tmin: average minimum temperature $\left({ }^{\circ} \mathrm{C}\right), \mathrm{P}$ : rainfall $(\mathrm{mm})$.

\begin{tabular}{|lccccccc|}
\hline & Jan & Feb & Mar & Apr & May & Jun & \\
\hline Tm & 4.5 & 6.0 & 7.8 & 11.5 & 14.6 & 18.2 & \\
\hline Tmax & 8.1 & 11.6 & 14.1 & 18.1 & 21.5 & 25.9 & \\
\hline Tmin & 1.1 & 1.0 & 1.8 & 4.9 & 7.9 & 10.9 & \\
\hline P & 39.7 & 32.2 & 22.9 & 50.2 & 75.9 & 41.3 & \\
\hline & Jul & Aug & Sep & Oct & Nov & Dec & Year \\
\hline Tm & 21.2 & 21.5 & 17.8 & 12.6 & 7.3 & 3.9 & 12.3 \\
\hline Tmax & 29.7 & 30.1 & 25.9 & 19.9 & 12.4 & 8.2 & 18.8 \\
\hline Tmin & 12.5 & 13.1 & 10.1 & 5.9 & 2.6 & -0.2 & 5.9 \\
\hline P & 1.3 & 10.9 & 30.3 & 46.3 & 44.2 & 67.1 & 462 \\
\hline
\end{tabular}

Table 3. Grape yield (t/ha) of treatments: 1.04, 1.40, 1.80 . Statistical significance (Sig): ns, no significant; *, $\mathrm{p}<0.05$, **, $\mathrm{p}<0.01$ (for all tables).

\begin{tabular}{|lcccccc|}
\hline Treat. & $\mathbf{2 0 0 7}$ & $\mathbf{2 0 0 8}$ & $\mathbf{2 0 0 9}$ & $\mathbf{2 0 1 0}$ & $\mathbf{2 0 1 1}$ & Aver. \\
\hline $\mathbf{1 . 0 4}$ & 4.80 & 4.07 & 3.55 & 3.09 & $4.43 \mathrm{c}$ & 3.99 \\
\hline $\mathbf{1 . 4 0}$ & 4.96 & 4.20 & 3.73 & 3.20 & $5.15 \mathrm{a}$ & 4.25 \\
\hline $\mathbf{1 . 8 0}$ & 4.96 & 4.37 & 3.70 & 2.99 & $4.73 \mathrm{~b}$ & 4.15 \\
\hline Sig & ns & ns & ns & ns & $* *$ & \\
\hline
\end{tabular}

Table 4. Cluster weight (g) of treatments: 1.04, 1.40, 1.80.

\begin{tabular}{|lcccccc|}
\hline Treat. & $\mathbf{2 0 0 7}$ & $\mathbf{2 0 0 8}$ & $\mathbf{2 0 0 9}$ & $\mathbf{2 0 1 0}$ & $\mathbf{2 0 1 1}$ & Aver. \\
\hline $\mathbf{1 . 0 4}$ & 310 & $297 \mathrm{~b}$ & $266 \mathrm{~b}$ & 269 & $286 \mathrm{~b}$ & 286 \\
\hline $\mathbf{1 . 4 0}$ & 291 & $319 \mathrm{a}$ & $293 \mathrm{a}$ & 282 & $314 \mathrm{a}$ & 300 \\
\hline $\mathbf{1 . 8 0}$ & 296 & $308 \mathrm{ab}$ & $284 \mathrm{a}$ & 265 & $300 \mathrm{ab}$ & 291 \\
\hline Sig & $\mathrm{ns}$ & $*$ & $*$ & $\mathrm{~ns}$ & $*$ & \\
\hline
\end{tabular}

\section{Results and discussion}

\subsection{Grape yield}

The grape yield showed a general tendency of treatment 1.40 to obtain a slightly higher level than 1.80 , which, in turn, has been shown somewhat larger than treatment 1.04 , with only an increase of the greatest with respect to the smallest of $6.5 \%$. The few differences noted between treatments were only statistically significant one of the years of study (Table 3). A similar trend to grape yield was observed in the cluster weight, so that the treatment 1.40 has shown a cluster weight somewhat greater than the 1.80, and the latter in turn slightly larger than the 1.04, with only an average increase of the greatest respect to the smallest of about $5 \%$, with statistically significant differences found some years of the study (Table 4). The cluster weight, therefore, mostly explains the slight tendency of the productive response of established treatments, since the number of clusters per linear meter has not practically shown differences between treatments, except for the first year of study, in which the treatment 1.04 provided fewer clusters per meter of trellis (Table 5).

Regarding the cluster weight, the number of berries per cluster also showed a slight tendency of treatment 1.40 to present slightly higher values than the other two treatments, with an average increase of $5 \%$ compared to 
Table 5. Clusters/meter, of treatments: 1.04, 1.40, 1.80.

\begin{tabular}{|lcccccc|}
\hline Treat. & $\mathbf{2 0 0 7}$ & $\mathbf{2 0 0 8}$ & $\mathbf{2 0 0 9}$ & $\mathbf{2 0 1 0}$ & $\mathbf{2 0 1 1}$ & Aver. \\
\hline $\mathbf{1 . 0 4}$ & $15.7 \mathrm{~b}$ & 13.8 & 13.5 & 11.8 & 15.6 & 14.1 \\
\hline $\mathbf{1 . 4 0}$ & $17.3 \mathrm{a}$ & 13.2 & 12.7 & 11.6 & 16.6 & 14.3 \\
\hline $\mathbf{1 . 8 0}$ & 16.7 a & 14.2 & 13.1 & 11.3 & 16.1 & 14.3 \\
\hline Sig & $*$ & $\mathrm{~ns}$ & $\mathrm{~ns}$ & $\mathrm{~ns}$ & $\mathrm{~ns}$ & \\
\hline
\end{tabular}

Table 6. Berries/cluster, of treatments: 1.04, 1.40, 1.80.

\begin{tabular}{|lcccccc|}
\hline Treat. & $\mathbf{2 0 0 7}$ & $\mathbf{2 0 0 8}$ & $\mathbf{2 0 0 9}$ & $\mathbf{2 0 1 0}$ & $\mathbf{2 0 1 1}$ & Aver. \\
\hline $\mathbf{1 . 0 4}$ & $146 \mathrm{a}$ & $135 \mathrm{~b}$ & 132 & 133 & $129 \mathrm{~b}$ & 135 \\
\hline $\mathbf{1 . 4 0}$ & $140 \mathrm{a}$ & $148 \mathrm{a}$ & 144 & 140 & $145 \mathrm{a}$ & 143 \\
\hline $\mathbf{1 . 8 0}$ & $131 \mathrm{~b}$ & $138 \mathrm{~b}$ & 136 & 133 & $142 \mathrm{a}$ & 136 \\
\hline Sig & $*$ & $*$ & $\mathrm{~ns}$ & $\mathrm{~ns}$ & $*$ & \\
\hline
\end{tabular}

Table 7. Berry weight (g) of treatments: 1.04, 1.40, 1.80 .

\begin{tabular}{|lcccccc|}
\hline Treat. & $\mathbf{2 0 0 7}$ & $\mathbf{2 0 0 8}$ & $\mathbf{2 0 0 9}$ & $\mathbf{2 0 1 0}$ & $\mathbf{2 0 1 1}$ & Aver. \\
\hline $\mathbf{1 . 0 4}$ & $2.13 \mathrm{~b}$ & 2.21 & 2.02 & 2.02 & 2.21 & 2.12 \\
\hline $\mathbf{1 . 4 0}$ & $2.08 \mathrm{~b}$ & 2.17 & 2.04 & 2.01 & 2.17 & 2.09 \\
\hline $\mathbf{1 . 8 0}$ & $2.26 \mathrm{a}$ & 2.24 & 2.10 & 1.99 & 2.12 & 2.14 \\
\hline Sig & $*$ & $\mathrm{~ns}$ & $\mathrm{~ns}$ & $\mathrm{~ns}$ & $\mathrm{~ns}$ & \\
\hline
\end{tabular}

Table 8. Clusters/shoot, of treatments: 1.04, 1.40, 1.80.

\begin{tabular}{|lcccccc|}
\hline Treat. & $\mathbf{2 0 0 7}$ & $\mathbf{2 0 0 8}$ & $\mathbf{2 0 0 9}$ & $\mathbf{2 0 1 0}$ & $\mathbf{2 0 1 1}$ & Aver. \\
\hline $\mathbf{1 . 0 4}$ & 1.37 & 1.31 & $1.19 \mathrm{~b}$ & $1.07 \mathrm{~b}$ & $1.32 \mathrm{~b}$ & 1.25 \\
\hline $\mathbf{1 . 4 0}$ & 1.46 & 1.24 & $1.19 \mathrm{~b}$ & $1.07 \mathrm{~b}$ & $1.41 \mathrm{ab}$ & 1.27 \\
\hline $\mathbf{1 . 8 0}$ & 1.50 & 1.40 & $1.33 \mathrm{a}$ & $1.18 \mathrm{a}$ & $1.52 \mathrm{a}$ & 1.39 \\
\hline Sig & ns & ns & $*$ & $*$ & $*$ & \\
\hline
\end{tabular}

treatments 1.80 and 1.04 (Table 6). It has been observed that the differences were statistically significant some years. Regarding the berry weight, it has hardly been observed any tendency of the treatments to produce berries significantly higher or smaller, with a similar average berry weight of the three treatments, between 2.09 and 2.14 grams. The differences were statistically significant exceptionally the first year of study, in favor of treatment 1.80 (Table 7).

The real fertility, expressed as number of clusters per shoot of pruning, showed a higher mean value of treatment 1.80 than treatments 1.40 and 1.04 , with an average increase of $10 \%$, which has been corroborated by the existence of statistically significant differences in several years of study (Table 8).

\subsection{Vegetative growth}

The weight of pruning wood per unit area of soil decreased with increasing vine spacing, with statistically significant differences between treatments all the years of study. The average increase in weight of pruning wood of the highest treatment, 1.04, with respect to the lowest, 1.80, was about $15 \%$ (Table 9).

The weight of shoot has been largely responsible for the decline of pruning wood due to the increase of distance between vines regarding the treatment 1.04, which showed higher values than the other two treatments, with an average increase of $6 \%$ compared to them, having observed that these differences between treatments were statistically significant some years of study (Table 10).
Table 9. Pruning wood weight $(\mathrm{g} / \mathrm{m})$ of treatments: $1.04,1.40$, 1.80. Statistical significance (Sig): ns, no significant; *, p <0.05, **, $\mathrm{p}<0.01$ (for all tables).

\begin{tabular}{|lcccccc|}
\hline Treat. & $\mathbf{2 0 0 7}$ & $\mathbf{2 0 0 8}$ & $\mathbf{2 0 0 9}$ & $\mathbf{2 0 1 0}$ & $\mathbf{2 0 1 1}$ & Aver. \\
\hline $\mathbf{1 . 0 4}$ & $775 \mathrm{a}$ & $853 \mathrm{a}$ & $574 \mathrm{a}$ & $754 \mathrm{a}$ & $802 \mathrm{a}$ & 752 \\
\hline $\mathbf{1 . 4 0}$ & $762 \mathrm{a}$ & $790 \mathrm{~b}$ & $525 \mathrm{~b}$ & $699 \mathrm{~b}$ & $761 \mathrm{~b}$ & 707 \\
\hline $\mathbf{1 . 8 0}$ & $711 \mathrm{~b}$ & $714 \mathrm{c}$ & $471 \mathrm{c}$ & $662 \mathrm{c}$ & $713 \mathrm{c}$ & 654 \\
\hline Sig & $* *$ & $* *$ & $*$ & $*$ & $*$ & \\
\hline
\end{tabular}

Table 10. Shoot weight $(\mathrm{g})$ of treatments: 1.04, 1.40, 1.80 .

\begin{tabular}{|lcccccc|}
\hline Treat. & $\mathbf{2 0 0 7}$ & $\mathbf{2 0 0 8}$ & $\mathbf{2 0 0 9}$ & $\mathbf{2 0 1 0}$ & $\mathbf{2 0 1 1}$ & Aver. \\
\hline $\mathbf{1 . 0 4}$ & $67.3 \mathrm{a}$ & $81.5 \mathrm{a}$ & 50.8 & 69.9 & 68.8 & 67.7 \\
\hline $\mathbf{1 . 4 0}$ & $64.9 \mathrm{~b}$ & $74.3 \mathrm{~b}$ & 49.4 & 65.9 & 64.8 & 63.9 \\
\hline $\mathbf{1 . 8 0}$ & $64.1 \mathrm{~b}$ & $70.2 \mathrm{~b}$ & 47.6 & 70.7 & 67.8 & 64.1 \\
\hline Sig & $*$ & $*$ & $\mathrm{~ns}$ & $\mathrm{~ns}$ & $\mathrm{~ns}$ & \\
\hline
\end{tabular}

Table 11. Shoots / meter, of treatments: $1.04,1.40,1.80$.

\begin{tabular}{|lcccccc|}
\hline Treat. & $\mathbf{2 0 0 7}$ & $\mathbf{2 0 0 8}$ & $\mathbf{2 0 0 9}$ & $\mathbf{2 0 1 0}$ & $\mathbf{2 0 1 1}$ & Aver. \\
\hline $\mathbf{1 . 0 4}$ & 11.5 & 10.5 & $11.3 \mathrm{a}$ & $11.0 \mathrm{a}$ & $11.8 \mathrm{a}$ & 11.2 \\
\hline $\mathbf{1 . 4 0}$ & 11.8 & 10.7 & $10.6 \mathrm{ab}$ & $10.8 \mathrm{a}$ & $11.8 \mathrm{a}$ & 11.1 \\
\hline $\mathbf{1 . 8 0}$ & 11.1 & 10.2 & $9.9 \mathrm{~b}$ & $9.6 \mathrm{~b}$ & $10.6 \mathrm{~b}$ & 10.3 \\
\hline Sig & ns & ns & $*$ & $*$ & $* *$ & \\
\hline
\end{tabular}

Table 12. Index of Ravaz, of treatments: 1.04, 1.40, 1.80.

\begin{tabular}{|lcccccc|}
\hline Treat. & $\mathbf{2 0 0 7}$ & $\mathbf{2 0 0 8}$ & $\mathbf{2 0 0 9}$ & $\mathbf{2 0 1 0}$ & $\mathbf{2 0 1 1}$ & Aver. \\
\hline $\mathbf{1 . 0 4}$ & $6.20 \mathrm{~b}$ & $4.78 \mathrm{c}$ & $6.18 \mathrm{c}$ & 4.10 & $5.56 \mathrm{~b}$ & 5.36 \\
\hline $\mathbf{1 . 4 0}$ & $6.51 \mathrm{ab}$ & $5.37 \mathrm{~b}$ & $7.14 \mathrm{~b}$ & 4.57 & $6.77 \mathrm{a}$ & 6.07 \\
\hline $\mathbf{1 . 8 0}$ & $7.00 \mathrm{a}$ & $6.15 \mathrm{a}$ & $7.94 \mathrm{a}$ & 4.52 & $6.63 \mathrm{a}$ & 6.45 \\
\hline Sig & $*$ & $* *$ & $* *$ & $\mathrm{~ns}$ & $*$ & \\
\hline
\end{tabular}

Table 13. Soluble solids ( ${ }^{\circ}$ Brix) of treatments: 1.04, 1.40, 1.80 . Statistical significance (Sig): ns, no significant; *, p $<0.05$, **, $\mathrm{p}<0.01$ (for all tables).

\begin{tabular}{|lcccccc|}
\hline Treat. & $\mathbf{2 0 0 7}$ & $\mathbf{2 0 0 8}$ & $\mathbf{2 0 0 9}$ & $\mathbf{2 0 1 0}$ & $\mathbf{2 0 1 1}$ & Aver. \\
\hline $\mathbf{1 . 0 4}$ & 21.9 & 21.2 & 24.3 & 24.7 & 23.6 & 23.14 \\
\hline $\mathbf{1 . 4 0}$ & 22.3 & 21.4 & 23.7 & 25.1 & 23.2 & 23.14 \\
\hline $\mathbf{1 . 8 0}$ & 21.8 & 20.9 & 24.2 & 25.2 & 23.5 & 23.12 \\
\hline Sig & ns & ns & ns & ns & ns & \\
\hline
\end{tabular}

The number of shoots per linear meter also showed differences between treatment 1.80 , with lower values (mean of 10.3), and the two other treatments (mean values of 11.2 and 11.1), with an average decrease of $8 \%$, in such a way that they have been statistically significant several years of study (Table 11).

The Ravaz index has shown a tendency to increase with the distance between vines, due mainly to the decrease in the weight of pruning wood, having observed statistically significant differences between experimental treatments most years (Table 12).

\subsection{Grape composition}

The concentration of soluble solids ( ${ }^{\circ}$ Brix) has not changed with the distance between vines, having found no statistically significant differences in sugar concentration between treatments either year of study (Table 13). 
Table 14. $\mathrm{pH}$ of treatments: $1.04,1.40,1.80$.

\begin{tabular}{|lcccccc|}
\hline Treat. & $\mathbf{2 0 0 7}$ & $\mathbf{2 0 0 8}$ & $\mathbf{2 0 0 9}$ & $\mathbf{2 0 1 0}$ & $\mathbf{2 0 1 1}$ & Aver. \\
\hline $\mathbf{1 . 0 4}$ & 3.15 & 3.03 & 3.37 & 3.51 & 3.48 a & 3.31 \\
\hline $\mathbf{1 . 4 0}$ & 3.12 & 3.00 & 3.33 & 3.48 & $3.42 \mathrm{~b}$ & 3.27 \\
\hline $\mathbf{1 . 8 0}$ & 3.08 & 3.03 & 3.35 & 3.51 & 3.47 a & 3.29 \\
\hline Sig & ns & ns & ns & ns & $*$ & \\
\hline
\end{tabular}

Table 15. Titratable acidity (g/L) of treatments: 1.04, 1.40, 1.80 .

\begin{tabular}{|lcccccc|}
\hline Treat. & $\mathbf{2 0 0 7}$ & $\mathbf{2 0 0 8}$ & $\mathbf{2 0 0 9}$ & $\mathbf{2 0 1 0}$ & $\mathbf{2 0 1 1}$ & Aver. \\
\hline $\mathbf{1 . 0 4}$ & 7.55 & 8.88 b & 5.14 & 6.01 & 5.55 & 6.63 \\
\hline $\mathbf{1 . 4 0}$ & 7.78 & 9.18 a & 5.25 & 5.89 & 5.46 & 6.71 \\
\hline $\mathbf{1 . 8 0}$ & 7.65 & 8.75 b & 5.16 & 5.90 & 5.29 & 6.55 \\
\hline Sig & ns & $*$ & ns & ns & ns & \\
\hline
\end{tabular}

Table 16. Tartaric acid (g/L) of treatments: 1.04, 1.40, 1.80 .

\begin{tabular}{|ccccc|}
\hline Treat. & $\mathbf{2 0 0 9}$ & $\mathbf{2 0 1 0}$ & $\mathbf{2 0 1 1}$ & Aver. \\
\hline $\mathbf{1 . 0 4}$ & 5.42 & 6.01 & 6.11 & 5.85 \\
\hline $\mathbf{1 . 4 0}$ & 5.33 & 5.89 & 5.98 & 5.73 \\
\hline $\mathbf{1 . 8 0}$ & 5.42 & 5.90 & 6.02 & 5.78 \\
\hline Sig & ns & ns & ns & \\
\hline
\end{tabular}

Table 17. Malic acid (g/L) of treatments: 1.04, 1.40, 1.80.

\begin{tabular}{|ccccc|}
\hline Treat. & $\mathbf{2 0 0 9}$ & $\mathbf{2 0 1 0}$ & $\mathbf{2 0 1 1}$ & Aver. \\
\hline $\mathbf{1 . 0 4}$ & 2.28 & 2.62 & 2.06 & 2.32 \\
\hline $\mathbf{1 . 4 0}$ & 2.31 & 2.49 & 2.04 & 2.28 \\
\hline $\mathbf{1 . 8 0}$ & 2.24 & 2.55 & 1.95 & 2.25 \\
\hline Sig & ns & ns & ns & \\
\hline
\end{tabular}

The $\mathrm{pH}$ values were quite similar in the three treatments of distance between vines studied, without remarkable annual differences which obviously have not been statistically significant, except for the last year (Table 14). The titratable acidity (g/L) neither has presented significant differences between treatments, which were statistically significant only in 2008, a campaign of fairly high acidity, with a higher value of treatment 1.40 and lower of treatment 1.80 (Table 15).

With a similar trend, the tartaric acid $(\mathrm{g} / \mathrm{L})$ has not shown remarkable differences between treatments in the three years that this parameter was analyzed, which was reflected in no cases of statistically significance (Table 16). The malic acid ( $\mathrm{g} / \mathrm{L})$ neither has presented notable differences between treatments, with very similar values in the three established treatments of vine distance and naturally without having detected any statistically significant difference between treatments (Table 17).

The potassium showed higher concentration in grapes from smaller distance between vines, $1.04 \mathrm{~m}$, than in grapes from the other two vine distances, accounting for an average increase with respect to these of $6 \%$. These differences have been statistically significant in two of the three years of study of this parameter (Table 18). The total polyphenol index has hardly shown little differences between treatments, which have been of little quantitative importance in any of the years in which they were statistically significant in favor of treatment 1.80 with respect to treatment 1.04 or treatment 1.40 (Table 19).
Table 18. Potassium (mg/L) of treatments: 1.04, 1.40, 1.80.

\begin{tabular}{|ccccc|}
\hline Treat. & $\mathbf{2 0 0 9}$ & $\mathbf{2 0 1 0}$ & $\mathbf{2 0 1 1}$ & Aver. \\
\hline $\mathbf{1 . 0 4}$ & 1598 & 1870 a & 1643 a & 1704 \\
\hline $\mathbf{1 . 4 0}$ & 1563 & $1718 \mathrm{~b}$ & $1543 \mathrm{c}$ & 1608 \\
\hline $\mathbf{1 . 8 0}$ & 1525 & $1685 \mathrm{~b}$ & $1595 \mathrm{~b}$ & 1602 \\
\hline Sig & ns & $* *$ & $*$ & \\
\hline
\end{tabular}

Table 19. Index of total phenols, of treatments: $1.04,1.40,1.80$.

\begin{tabular}{|lcccccc|}
\hline Treat. & $\mathbf{2 0 0 7}$ & $\mathbf{2 0 0 8}$ & $\mathbf{2 0 0 9}$ & $\mathbf{2 0 1 0}$ & $\mathbf{2 0 1 1}$ & Aver. \\
\hline $\mathbf{1 . 0 4}$ & 15.8 & $23.1 \mathrm{~b}$ & 17.5 & 23.3 & $17.3 \mathrm{ab}$ & 19.4 \\
\hline $\mathbf{1 . 4 0}$ & 14.8 & $24.5 \mathrm{a}$ & 17.5 & 22.5 & $15.8 \mathrm{~b}$ & 19.0 \\
\hline $\mathbf{1 . 8 0}$ & 13.8 & $25.2 \mathrm{a}$ & 17.5 & 24.0 & $18.5 \mathrm{a}$ & 19.8 \\
\hline Sig & ns & $*$ & ns & ns & $*$ & \\
\hline
\end{tabular}

\section{Conclusions}

The variation of the distance between vines has had little effect on grape production, although the treatment of intermediate distance, $1.40 \mathrm{~m}$, showed a slightly higher grape yield than $1.80 \mathrm{~m}$ and this slightly higher than $1.04 \mathrm{~m}$, with an increase of the greatest compared to the lowest of about $6.5 \%$. Overall, this slight increase has been mainly due to the variation of the cluster weight, which has followed the same trend as the grape yield, while the number of clusters per meter has not been substantially altered. The number of berries per cluster has been more related to the variation of the cluster weight than the individual berry weight, which has shown a very similar value in the three treatments studied.

The weight of pruning wood per unit area of soil has clearly decreased with increasing distance between vines every year of study, with an average increase of $15 \%$ of the highest treatment, 1.04, relative to the lowest treatment, 1.80. The weight of shoot has been largely responsible for this decline, although with a smaller average increase of $6 \%$ for treatment 1.04 , since the number of shoots per linear meter has also shown some unfavorable differences for treatment 1.80 , with a decrease of $8 \%$. The Ravaz index has shown a tendency to increase with the distance between vines, derived from the decrease in weight of pruning wood.

The variation of the distance between vines has not modified remarkably most of the parameters of grape composition analyzed in the study. Thus, the concentration of soluble solids, the $\mathrm{pH}$, the titratable acidity, the tartaric acid and the malic acid have hardly changed with the change of the distance between vines. Uniquely, the potassium concentration has presented somewhat higher value in grapes from the lowest distance between vines, $1,04 \mathrm{~m}$, than in grapes from the other two distances, whereas the total polyphenol index showed hardly no differences between treatments, which were of little quantitative importance in any year in which they appeared slightly favorable to the distance of $1.80 \mathrm{~m}$.

Ultimately, the reduction of distance between vines favored vegetative growth, through the weight of shoot, while the grape yield was slightly higher with the intermediate vine distance, $1.40 \mathrm{~m}$, through the weight of cluster. In qualitative terms, the variation of the distance between vines did not modify significantly the basic 
composition of grapes. Therefore, the choice of the vine distance involves the desirability of jointly assessing the potential effects in terms of production and economic objectives of the new plantations in accordance with the characteristics of each growing situation.

The development of this study has been possible thanks to the collaboration of the winery Finca Museum, owner of the vineyard, as well as the analytical contribution of Enology Station of Castilla y León (Rueda, Valladolid), the financial contribution of the Junta de Castilla y León and the FEDER, and of course, the help from the group of Viticulture at ITACyL.

\section{References}

[1] J. Yuste, C. Arranz. "Respuesta a la variación de la distancia entre cepas de Tempranillo en la D.O. Arlanza, conducidas en espaldera y cultivadas en secano". Vida Rural 359: 32-36 (2013)

[2] M.A. Pérez. "Densidad de plantación y riego: Aspectos ecofisiológicos, agronómicos y calidad de la uva en cv. Tempranillo (Vitis vinifera L.)". Tesis Doctoral. Dpto. Producción vegetal: Fitotecnia, Universidad Politécnica de Madrid. 287 p (2002)

[3] F. Murisier, V. Zufferey. "Influence de la densité de plantation sur le comportement agronomique de la vigne et sur la qualité des vins: essai sur Chasselas. II Résultats oenologiques“. Revue Suisse Vitic. Arboric. Hortic. 36 (1): 45-49 (2004)

[4] F. Murisier, M. Ferretti. "Densité de plantation sur le rang: effects sur le rendement et la qualité du raisin“. Revue Suisse Vitic. Arboric. Hortic. 28 (5): 293-300 (1996)

[5] O. Silvestroni, T. Lattanzi, E. Manni, L. Borghesi. "Distanze sulla fila e forme di allevamento: risultati di prove sui vitigni Verdicchio e Montepulciano". L'informatore agrario 48: 51 (2003)

[6] C. Intrieri, I. Filippetti, S. Ramazzotti. "Concetti di base sulle distanze di impianto in viticoltura". L'informatore agrario 48: 41-47 (2003)

[7] M. Remoué, C. Lemaître. "Comparaison de differentes densités de plantation et methodes de culture du sol (non culture et enherbement permanent) ". Connaissance Vigne Vin 19 (4): 197-206 (1985)

[8] M.V. Alburquerque, C. Cascajo, R. Vacas, E. Barajas, J. Yuste. "Influencia de la distancia entre cepas en la variedad Tempranillo“. Vida Rural 226: 34-38 (2006)

[9] E. Barajas, J. Yuste. "Influencia de la densidad de plantación en cv. Tempranillo en dos Denominaciones de Origen a lo largo del valle del río Duero". II International Congress of Mountain and Steep Slope Viticulture (CERVIM). Monforte de Lemos, Orense (España). 184 p (2008)

[10] R. Planas. "Incidence de la densité de plantation. Application au vignoble audois“. Progrès Agricole et Viticole 115 (4): 89-92 (1998)

[11] J. Yuste, C. Arranz, E. Barajas, P. Sánchez-Llorente. "Densidad de plantación en condiciones semiáridas: efectos productivos y cualitativos en la variedad Tempranillo cultivada en vaso en condiciones de riego deficitario". Vticultura/Enología Profesional 116: 5-13 (2008)

[12] J. Yuste, J.L. Asensio, M.V. Alburquerque. "Modificación del crecimiento del pámpano y de la baya a través del riego y la densidad de plantación en la variedad Tempranillo". La semana vitivinícola 3273: 1957-1962 (2009)

[13] E. Barajas. "Comportamiento fisiológico y agronómico y calidad de la uva de la variedad Tempranillo, en función de la distancia entre cepas, en el valle del río Duero". Tesis Doctoral. Departamento de Producción Vegetal y Recursos Forestales, Universidad de Valladolid. 333 p (2010)

[14] J. Yuste, M.V. Alburquerque, E. Barajas, J.R. Yuste. "Densidad de plantación: efectos productivos, vegetativos y cualitativos en cv. Tempranillo cultivado en espaldera en el valle del Duero". I Jornadas de Viticultura y Enología de la Sociedad Española de Ciencias Hortícolas (aún sin publicar), (2014)

[15] J. Yuste, E. Barajas, J.R. Yuste. "Densidad de plantación: efectos productivos y cualitativos en Tempranillo cultivado en vaso en el valle del Duero". 29a Reunión del Grupo de Trabajo de Experimentación en Viticultura y Enología (GTEVE), Logroño, 6-7 mayo (2014) 